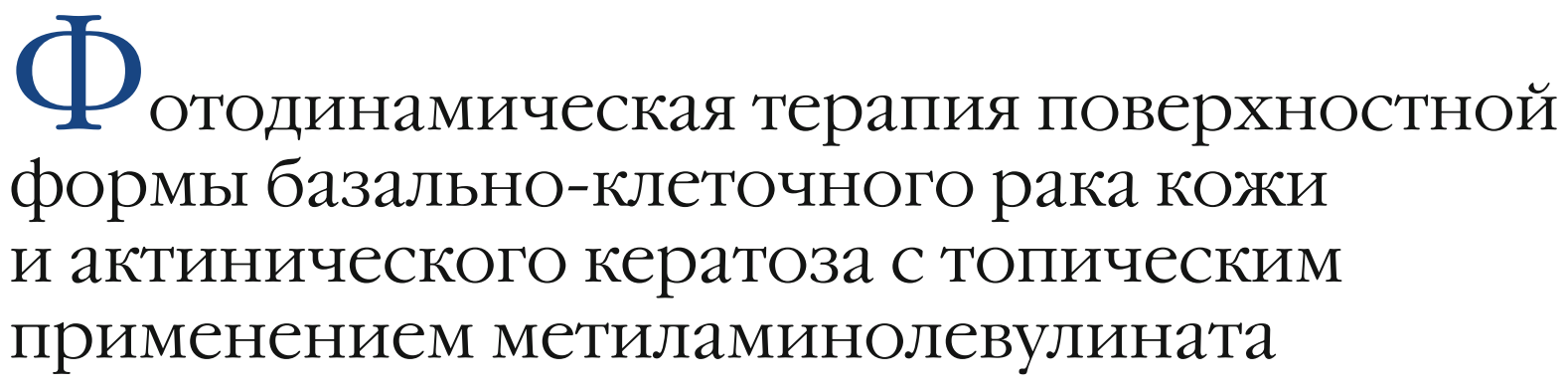

\begin{abstract}
А.А. Кубанова, А.А. Кубанов, И.Н. Кондрахина, Н.В. Грибанов
ФГБУ «Государственный научный центр дерматовенерологии и косметологии» Минздрава России 107076, Москва, ул. Короленко, д. 3, стр. 6
\end{abstract}

Цель. Оценить эфффективность фротодинамической терапии с наружным применением фротосенсибилизатора метиламинолевулината с последующим облучением видимым красным светом с длиной волны 630 нм в лечении пациентов с поверхностной формой базально-клеточного рака кожи и с актиническим кератозом.

Материал и методы. Под наблюдением находились 28 пациентов с диагнозом базально-клеточного рака кожи, поверхностной формы и 34 пациента с диагнозом актинического кератоза. Лечение методом фротодинамической терапии проводилось с применением светодиодной лампы, излучающей видимый красный свет с длиной волны 630 нм с суммарной дозой облучения 37 Дж/см². Всем пациентам проводилась конфокальная лазерная сканирующая in vivo микроскопия очагов поражения исходно и через 7, 30, 90 и 180 дней после лечения.

Результаты. Полный регресс патологических очагов отмечался у 25 (91\%) пациентов с диагнозом базальноклеточного рака кожи, поверхностной формы и у 30 (88,9\%) пациентов с диагнозом актинического кератоза через 30 дней после лечения. При проведении исследования методом конорокальной лазерной сканирующей in vivo микроскопии признаков заболеваний у этих пациентов не обнаружено.

Вывод. Фотодинамическая терапия с локальным применением метиламинолевулината и последующим облучением видимым красным светом с длиной волны 630 нм является эффективным способом лечения поверхностного базально-клеточного рака кожи и актинического кератоза.

Ключевые слова: фотодинамическая терапия, метиламинолевулинат, актинический кератоз, базалиома, неинвазивная диагностика. 


\title{
Photodynamic therapy of the surface form of basalioma and actinic keratosis with the topical administration of methyl aminolevulinate
}

\author{
A.A. Kubanova, A.A. Kubanov, I.N. Kondrakhina, N.V. Gribanov
}

State Research Center of Dermatovenereology and Cosmetology, Ministry of Healthcare of the Russian Federation Korolenko str., 3, bldg 6, Moscow, 107076, Russia

Goal. To assess the efficacy of the photodynamic therapy with the external use of methyl aminolevulinate as a photosensitizer with further irradiation with visible red light with the wavelength of $630 \mathrm{~nm}$ in the treatment of patients suffering from a surface form of basalioma and actinic keratosis.

Materials and methods. The study involved 28 patients diagnosed with the surface form of basalioma and 34 patients diagnosed with actinic keratosis. They underwent treatment by the photodynamic therapy method using a LED lamp radiating visible red light with the wavelength of $630 \mathrm{~nm}$, with the total dose of irradiation equal to $37 \mathrm{~J} / \mathrm{cm} 2$. All patients also underwent a confocal in vivo laser scanning microscopy of lesions at the baseline and after 7, 30, 90 and 180 days of treatment.

Results. Absolute regression of abnormal lesions was observed in 25 (91\%) patients diagnosed with the surface form of basalioma and $30(88.9 \%)$ patients diagnosed with actinic keratosis after 30 days of treatment. No signs of the diseases were revealed in these patients after examination by the method of confocal in vivo laser scanning microscopy.

Conclusion. The photodynamic therapy with the local administration of methyl aminolevulinate with further irradiation with visible red light with the wavelength of $630 \mathrm{~nm}$ is an efficient method of treatment of the surface form of basalioma and actinic keratosis.

Key words: photodynamic therapy, methyl aminolevulinate, actinic keratosis, basalioma, non-invasive diagnostics. 
По данным официальной статистики, в Российской Федерации в период с 2003 по 2013 г. уровень заболеваемости злокачественными новообразованиями кожи без учета меланомы увеличился на 27,02\%. Общий стандартизированный показатель распространенности злокачественных немеланомных новообразований кожи составил в 2013 г. 25,14 на 100000 населения [1]. В структуре немеланомных опухолей кожи наиболее часто встречается базально-клеточный рак, на долю которого приходится до 96,8\% всех новообразований в этой группе [2].

Согласно определению ВОЗ (1980), базально-клеточный рак кожи - местноинвазивная медленно распространяющаяся и редко метастазирующая опухоль, возникающая в эпидермисе или волосяных фролликулах и состоящая из клеток, которые имеют большое сходство с базальными клетками эпидермиса [3].

По современным представлениям, патогенез опухоли вызван нарушением регуляции сигнального пути Hedgehog (Hh), контролирующего диффреренцировку клеток в процессе эмбриогенеза. В норме в постнатальном этапе развития организма $\mathrm{Hh}$ сигналинг является неактивным, однако вследствие мутации гена, кодирующего трансдуктор данного сигнального пути - белок Smoothened (SMO), и гена, кодирующего его ингибитор - трансмембранный белок Patched (РТCH), происходит реактивация сигнального пути Hedgehog. Дальнейшая активация целевых генов GLI1 и GLI2 определяет ряд клеточных реакций: активацию пролиферации и антиапоптотические сигналы [4, 5]. Кроме того, в развитии базально-клеточного рака кожи также обнаруживаются мутации гена TP53, кодирующего белок онкосупрессор Р53, а также идентифицированы мутации CDKN2A локуса генов семейства ras [6, 7].

В соответствии с 7-м изданием международной TNM классификации стадий злокачественных новообразований базально-клеточный рак кожи классифицируется по первичной опухоли, статусу регионарных лимфратических сосудов, наличию отдаленных метастазов, гистологической степени злокачественности и фракторам риска [8].

В повседневной клинической практике используется классификация, включающая поверхностную, опухолевую, язвенную, пигментную и склеродермоподобную фрормы базально-клеточного рака кожи [9, 10].

Преимущественная локализация базально-клеточного рака отмечается на коже открытых участков тела. В 83,3\% случаев опухоль развивается на коже головы, при этом 96,48\% из них - на коже лица. Отмечается тенденция к увеличению частоты развития множественных фрорм базально-клеточного рака кожи, которая, по данным разных авторов, варьирует от 1 до $21,4 \%$ [11, 12].

Наиболее распространенным предраковым заболеванием кожи является актинический кератоз, являю- щийся частью непрерывного процесса пролиферации атипичных кератиноцитов и в конечном итоге фрормирования инвазивного плоскоклеточного рака [13, 14].

Риск трансорормации актинического кератоза в злокачественную эпителиальную опухоль оценивается разными авторами от 0,025 до 16\% [15, 16]. R. Rossi и соавт. считают актинический кератоз плоскоклеточным раком in situ, отмечая прогрессирование инвазии в 10\% случаев [17]. По данным V. Criscione, высыпания, клинически расцененные как актинический кератоз, в 1,56\% случаев при цитологическом и гистологическом исследованиях являлись базально-клеточным раком кожи и в 2,56\% случаев - плоскоклеточной карциномой [18].

Основным этиологическим фрактором развития актинического кератоза является длительное воздействие на кожу УФ-излучения, в особенности УФизлучения В-спектра (290-320 нм), вызывающего мутации гена TP53, кодирующего белок-онкосупрессор p53 [16]. Инактивация этого белка сопровождается снижением апоптотической активности в отношении генетически поврежденных клеток. Неконтролируемая пролиферация аберрантных кератиноцитов и процессы неоангиогенеза приводят к локальной дисплазии $[19,20]$, сопровождающейся появлением очагов на коже открытых участков тела, главным образом на лице, ушных раковинах, коже кистей рук, у мужчин с андрогенетической алопецией - на коже волосистой части головы [18].

В лечении актинического кератоза и базально-клеточного рака кожи применяются хирургическое иссечение с интра- и постоперационным гистологическим контролем, кюретаж, электродиссекация, химиодеструкция, лучевая терапия, крио- и лазеродеструкция, топические цитостатические препараты, фотодинамическая терапия, а также комбинации различных методов [21, 22]. Выбор метода лечения зависит от формы заболевания, локализации патологического процесса, количества и размера очагов поражения, вероятности повторного роста и рецидивирования заболевания, возможных эстетических последствий [22].

Одним из методов направленного лечения эпителиальных новообразований и предраковых заболеваний кожи, обладающих высокой избирательностью воздействия, является фотодинамическая терапия (ФДТ). Это метод деструкции опухолевой ткани, основанный на локальной активации селективно накопившегося фоотосенсибилизатора видимым красным светом, что в присутствии кислорода тканей приводит к развитию фотохимической реакции, разрушающей опухолевые клетки [23, 24]. ФДТ обладает рядом преимуществ, к которым относятся избирательность деструкции, малая инвазивность процедуры, возможность воздействовать на несколько очагов одновременно, возможность многократного применения процедуры, высокая эффрективность и отсутствие 
выраженных эстетических последствий в сравнении со стандартными процедурами [24, 25].

Существует большое количество различных фоотосенсибилизаторов, применяемых для ФДТ новообразований, различающихся главным образом по химическому строению и способу введения. Наиболее безопасным считается локальное введение фотосенсибилизатора непосредственно в патологический очаг [26]. Такая методика позволяет снизить токсичность фотоактивных веществ, отмечающуюся при системном введении препарата.

В дерматологической практике для топического применения используются препараты на основе аминолевулиновой кислоты, являющейся субстратом для синтеза порфириновых соединений. При нанесении препарата на поверхность патологического очага действующее вещество, поглощенное клетками-мишенями, приводит к накоплению фотоактивных порфриринов, главным образом протопорфирина IX, активизирующихся при воздействии света с определенной длиной волны. Последующий каскад фотохимических реакций приводит к образованию в тканях высокореактивных фрорм кислорода, окислительным процессам и повреждению мембраны клеток-мишеней [26-28]. Для увеличения глубины проникновения активного вещества в ткань и увеличения селективности воздействия были синтезированы липофильные эфиры аминолевулиновой кислоты, наиболее распространенным из которых является метиловый эфир - метиламинолевулинат [29, 30].

Имеется ряд отечественных работ, посвященных изучению аминолевулиновой кислоты в ФДТ больных с предраковыми заболеваниями и злокачественными новообразованиями кожи [31, 32]. Целью настоящего исследования явилась оценка эффрективности ФДТ с наружным применением метиламинолевулината с последующим облучением видимым красным светом с длиной волны 630 нм с суммарной дозой облучения 37 Дж/см² в лечении пациентов с поверхностной формой базально-клеточного рака кожи и с актиническим кератозом.

\section{Материал и методы}

Под наблюдением находились 62 пациента: 28 (17 мужчин и 11 женщин в возрасте от 44 до 78 лет) с цитологически подтвержденным диагнозом базально-клеточного рака кожи, поверхностной формы с давностью заболевания от 5 мес. до 3 лет и 34 пациента (12 мужчин, 22 женщины в возрасте от 48 до 87 лет) с актиническим кератозом с давностью заболевания от 7 мес. до 11 лет.

Всем пациентам с базально-клеточным раком кожи и актиническим кератозом проводилось исследование патологических очагов методом конфокальной лазерной сканирующей in vivo микроскопии (КЛСМ) с применением микроскопа Lucid Vivascope 1500 пе- ред лечением, через 7, 30, 90 и 180 дней после лечения. Определялись конфокально-микроскопические признаки базально-клеточного рака кожи: структуры с темным силуэтом, окруженные палисадообразно расположенными тяжистыми клетками, соответствующие базалоидным комплексам; поляризация ядер кератиноцитов шиповатого слоя эпидермиса; наличие сосудистой атипии в виде большого количества хаотично расположенных сосудов различного калибра. Определялись конфокально-микроскопические признаки актинического кератоза: полиморфизм кератиноцитов эпидермиса, неравномерное увеличение межклеточного пространства, расширение и удлинение видимых капилляров.

ФДТ проводилась с использованием светодиодной лампы Galderma Aktilite CL128, излучающей видимый красный свет с длиной волны 630 нм. За 3 ч до облучения на поверхность патологических очагов наносился крем метиламинолевулината с захватом 3-4 мм видимо здоровой ткани. Суммарная доза облучения составила 37 Дж/см² при экспозиции 7-8 мин.

Пациентам с актиническим кератозом процедура ФДТ проводилась однократно. Пациентам с базальноклеточным раком кожи ФДТ проводилась двукратно с интервалом 7 дней.

\section{Результаты}

При клиническом обследовании пациентов с диагнозом базально-клеточного рака, поверхностной фрормы отмечались патологические очаги в виде папул и бляшек округло-овальных очертаний белесоватого, ярко-розового или красного цвета, в некоторых случаях с эрозированной поверхностью и наличием серозно-геморрагической корочки. Размер очагов в наибольшем измерении составлял от 0,4 см до 3 см. У 22 $(78,6 \%)$ пациентов патологические очаги локализовались на коже лица: на коже щек и скуловой области у 12 (54,5\%), на коже лба - у 5 (22,5\%), на коже носа и переносицы - у 3 (13,5\%), на коже периоральной области - у 2 (9,5\%). У 6 (22,4\%) пациентов патологические очаги локализовались на коже туловища: на коже спины - у 4 (66,7\%), на коже живота - у 2 $(33,3 \%)$ У 25 (89,3\%) пациентов диагноз базальноклеточного рака был установлен впервые, у 3 (10,7\%) пациентов имел место повторный рост опухоли после проведенной ранее криодеструкции.

У пациентов с актиническим кератозом патологические очаги были представлены эритематозными, несколько инфильтрированными бляшками желтовато-красноватого или розового цвета с четкими границами, округлых или неправильных очертаний. У 12 $(36,4 \%)$ пациентов на поверхности очагов отмечались плотные чешуйки. Размер очагов варьировал от 0,5 до 4 см в наибольшем измерении. Локализация очагов на коже лица: на коже щек и скуловой области (25\%), в области носогубного треугольника (8,3\%), на коже 
носа и переносицы (25\%), на коже лба (16,6\%), на коже заушной области (8,3\%), на коже височной области (16,6\%). У 16 (48,5\%) пациентов высыпания были множественными и локализовались на коже лба, щек, носа и переносицы, их число составляло от 2 до 8.

У всех пациентов диагноз актинического кератоза был установлен впервые, предшествующего лечения не проводилось.

При исходном исследовании методом КЛСМ в патологических очагах пациентов с базально-клеточным раком кожи отмечалась поляризация ядер кератиноцитов на уровне шиповатого слоя эпидермиса, расширение и хаотичное расположение сосудов микроциркуляторного русла, у 24 (92,3\%) пациентов определялись базалоидные комплексы в виде темных структур, окруженных палисадообразно расположенными клетками (рис. 1a). У пациентов с актиническим кератозом в эпидермисе определялся полиморфизм кератиноцитов в сочетании с неравномерным увеличением межклеточного пространства, расширение и удлинение видимых капилляров (рис. 1б).

При проведении ФДТ все пациенты субъективно отмечали болезненность и жжение в очаге поражения во время облучения. Сразу после процедуры в области воздействия отмечались отек, эритема (рис. 3).

Через 7 дней после лечения клинически в области очага отмечались эритема, отек, образование струпа (см. рис. 3). Исследование методом КЛСМ во всех случаях выявило наличие единичных ярких дендритических клеток, соответствующих клеткам Лангерганса,

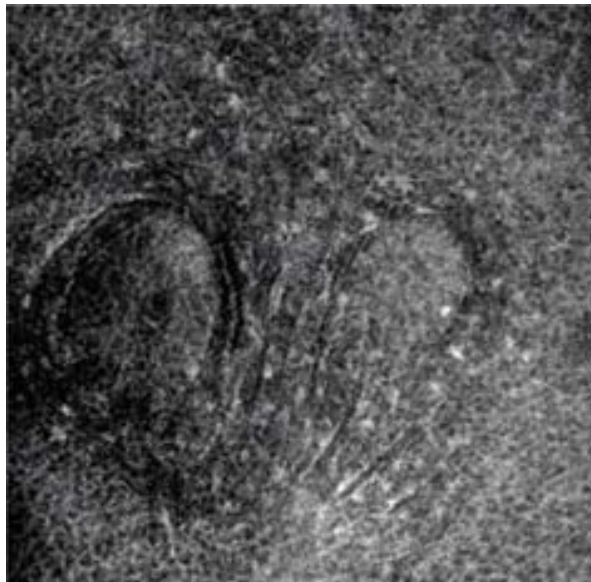

a

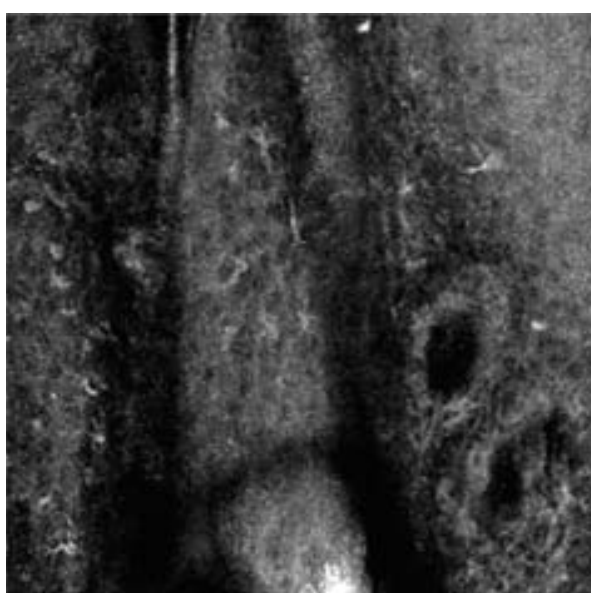

B

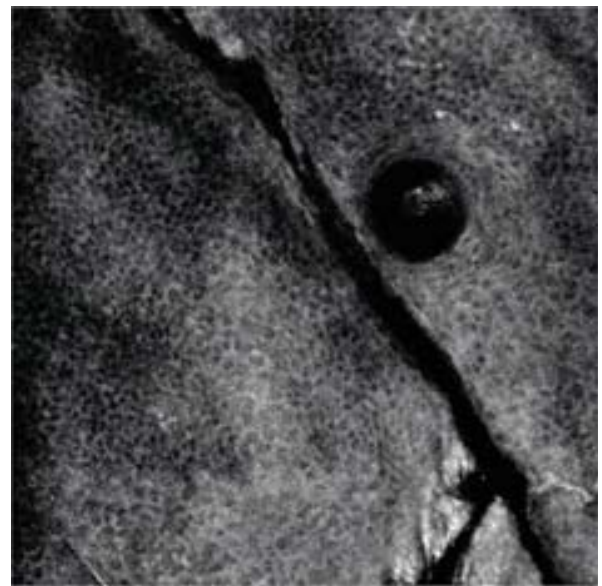

б

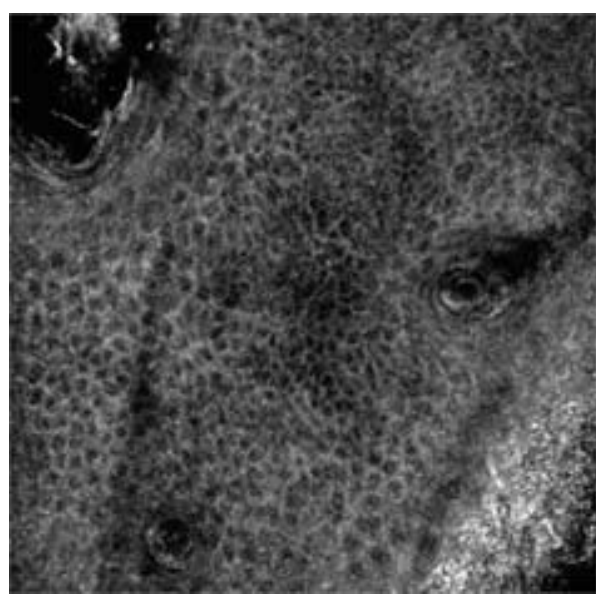

$\Gamma$

Конфокально-микроскопическое изображение патологического очага при поверхностном базально-клеточном раке кожи: базалоидный опухолевый комплекс (a); при актиническом кератозе: полиморфизм кератиноцитов (б). Конфокально-микроскопическое изображение эпидермиса в патологическом очаге базально-клеточного рака кожи через 7 дней после фотодинамической терапии (в); в патологическом очаге актинического кератоза через 1 мес. после фотодинамической терапии (г) 


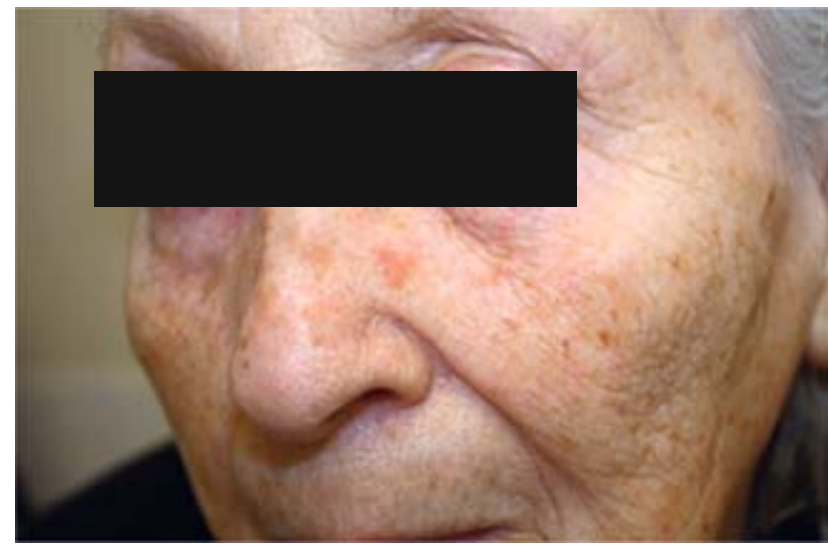

a

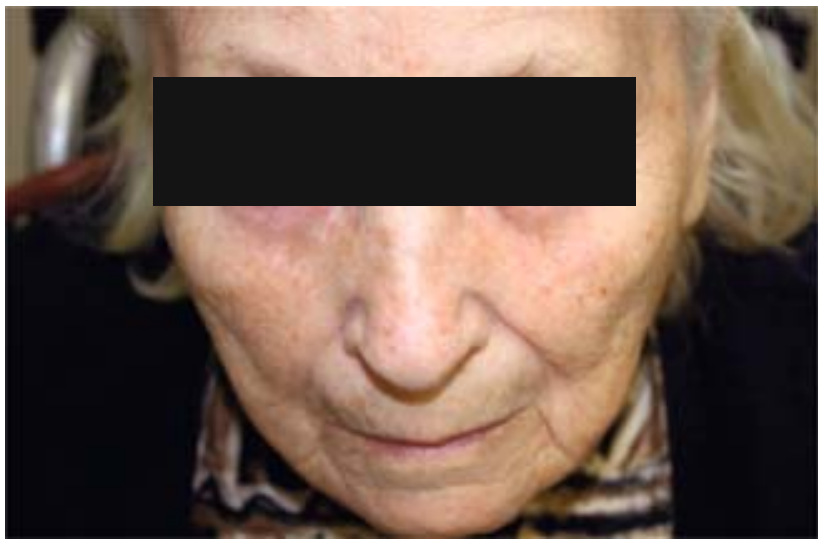

б

Рис. 2. Пациентка А. 82 лет с диагнозом актинический кератоз кожи лица: $а$ — до лечения; б - через 1 мес. после фотодинамической терапии

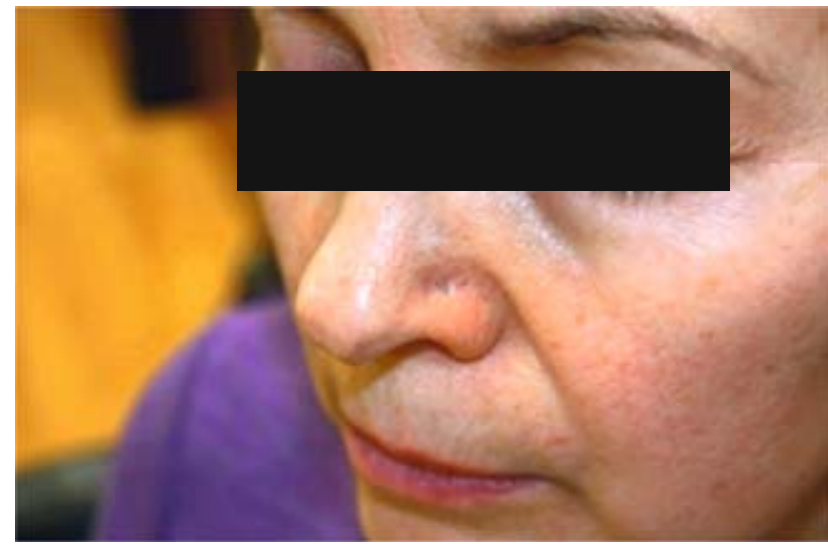

$a$

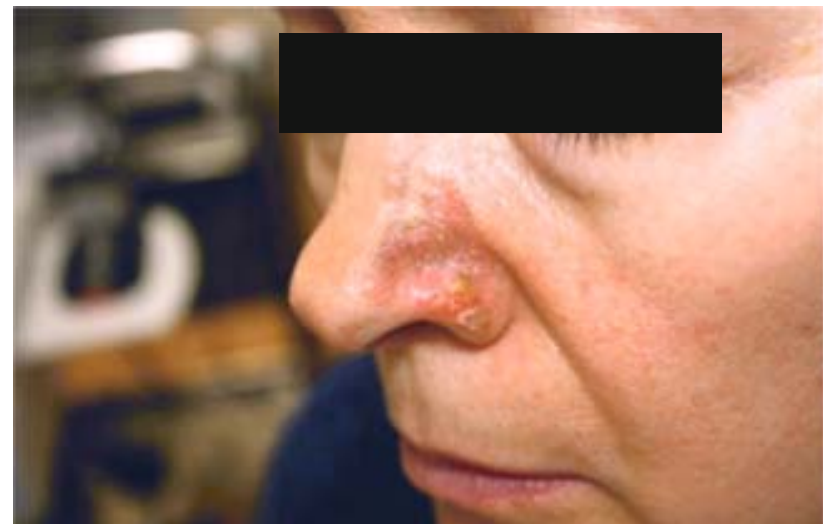

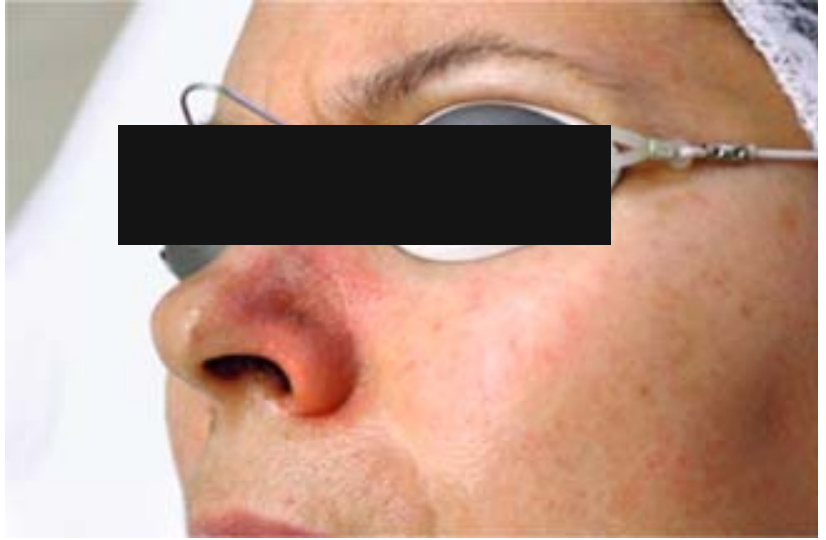

$\sigma$

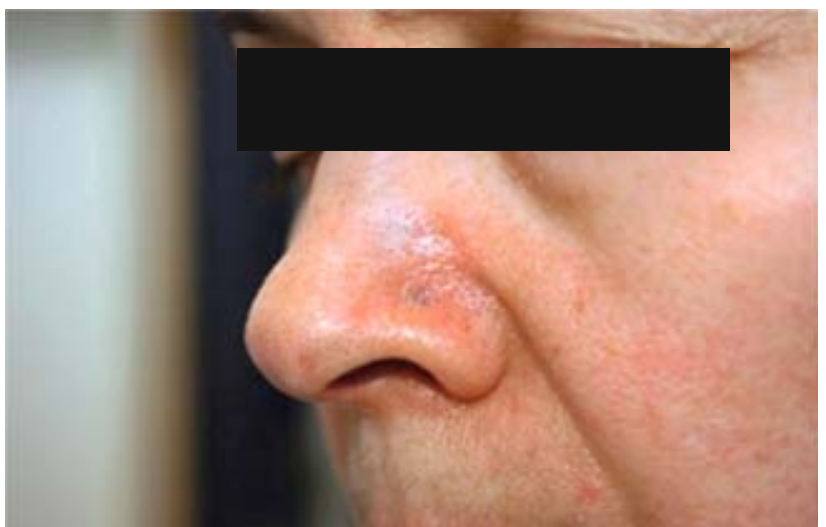

Пациентка Л. 53 лет с диагнозом поверхностная базалиома в области крыла носа:

Рис. 3. а - до лечения; б - сразу после проведения процедуры фотодинамической терапии (отмечается эритема и отек в области воздействия); в — через 7 дней после лечения (отмечается образование струпа в области воздействия); г - через 1 мес. после проведенной фотодинамической терапии 
расположенным в эпидермисе, и отдельные скопления светлых точечных структур, соответствующих лимфоцитарной воспалительной инфильтрации (рис. 1в).

Через 30 дней полный клинический регресс патологических очагов наблюдался у 25 (91\%) пациентов с базально-клеточным раком кожи и у 30 (88,9\%) пациентов с диагнозом актинического кератоза. Проведенное конфокально-микроскопическое исследование не выявило признаков заболевания у этих пациентов (рис. 1г).

У $3(11,1 \%)$ пациентов с актиническим кератозом и у 3 (9\%) пациентов с базально-клеточным раком кожи наблюдался частичный регресс патологических очагов с уменьшением их площади на $30-50 \%$. Исследование методом КЛСМ выявило у этих пациентов в оставшихся очагах признаки заболеваний: сохраняющегося клеточного полиморфизма в эпидермисе при актиническом кератозе и базалоидные комплексы и поляризованные ядра при базально-клеточном раке кожи. Этим пациентам была проведена повторная процедура ФДТ, после чего был отмечен полный клинический регресс патологических очагов, подтвержденный исследованием методом КЛСМ.

Клиническое обследование пациентов на 90-й и 180-й дни после лечения не выявило новых очагов поражения, образования рубцовой ткани, нарушений пигментации, длительной диффузной эритемы. Для исключения возможности субклинического рецидивирования патологического процесса в области воздействия проводилась повторная КЛСМ, не обнаружившая признаков заболеваний.

\section{Обсуждение}

Настоящим исследованием подтверждена эффрективность метиламинолевулината как топического фотосенсибилизатора для ФДТ поверхностного базально-клеточного рака кожи и актинического кератоза. По результатам КЛСМ, проведенной после лечения, признаков заболеваний не выявлено, что свидетельствует об отсутствии рецидива.
Эфрфективность аминолевулиновой кислоты в ФДТ базально-клеточного рака кожи и актинического кератоза подтверждена многими авторами. Однако в некоторых работах указана большая селективность накопления метиламинолевулината в тканях-мишенях по сравнению с аминолевулиновой кислотой, что свидетельствует о более глубоком проникновении активного вещества в очаг поражения при меньшем деструктивном воздействии на окружающую интактную ткань. Вследствие чего период накопления активных порфиринов при нанесении метиламинолевулината более короткий и составляет 3 ч. Преимуществом применения данного вещества также является слабая выраженность нежелательных явлений.

Применение светодиодной лампы с рассеянным светом увеличивает площадь облучения и обеспечивает световое воздействие на несколько очагов одновременно, что значительно ускоряет проведение ФДТ при мультифокальном поражении.

КЛСМ может применяться как метод неинвазивной диагностики и оценки эффективности лечения. Визуализация при данном исследовании сопоставима с гистологическим исследованием, но при этом не требуется взятия биопсийного материала.

Таким образом, ФДТ с наружным нанесением метиламинолевулината значительно расширяет арсенал средств лечения поверхностного базально-клеточного рака кожи и актинического кератоза.

\section{Заключение}

Исследование показало высокую эфффективность метиламинолевулината как топического фотосенсибилизатора для проведения ФДТ пациентов с поверхностным базально-клеточным раком кожи и актиническим кератозом.

Все пациенты отмечали хорошую переносимость процедур ФДТ, последствия лечения в виде отека, эритемы и образования струпа имели локальный и транзиторный характер, купировались самостоятельно в течение 10-14 дней. І
1. Kaprin A.D., Starinskij V.V., Petrova G.V. ZIokachestvennye novoobrazovaniya $\mathrm{v}$ Rossii $\mathrm{V}$ 2013 godu (Zabolevaemost' i smertnost'). M: MNIOI im. P.A. Gercena filial FGBU «FMIC im. P.A. Gercena» Minzdrava Rossii. 2015. [Каприн А.Д., Старинский В.В., Петрова Г.В. Злокачественные новообразования в России в 2013 году (Заболеваемость и смертность). М: МНИОИ им. П.А. Герцена - филиал ФГБУ «ФМИЦ им. П.А. Герцена» Минздрава России, 2015.]

\section{Литература}

2. Suhova T.E., Molochkov V.A., Romanko YU.S. i soavt. Lechenie bazal'nokletochnogo raka kozhi na sovermennom ehtape. Al'manah klinicheskoj mediciny. 2008; 18: 14—21. [Сухова T.E., Moлочков В.А., Романко Ю.С. и соавт. Лечение базальноклеточного рака кожи на соверменном этапе. Альманах клинической медицины. 2008; (18): 14-21.]

3. Gistologicheskaya klassifikaciya opuholej kozhi. VOZ. Zheneva, 1996. [Гистологическая классификация опухолей кожи. В03. Женева, 1996.]
4. Scales S.J., de Sauvage F.J. Mechanisms of Hedgehog pathway activation in cancer implications for therapy. Trends Pharmacol Sci. 2009; 30 (6): 303-312.

5. Ozgur O.K., Yin V., Chou E. et al. Hedgehog pathway inhibition for locally advanced periocular basal cell carcinoma and basal cell nevus syndrome. Am J Ophthalmol. 2015; Epub ahead of print. 
6. Abidi A. Hedgehog signaling pathway: a novel target for cancer therapy: vismodegib, a promising therapeutic option in treatment of basal cell carcinomas. Indian J Pharmacol. 2014; 46: 3-12.

7. Otsuka A., Levesque M.P., Dummer R., Kabashima K. Hedgehog signaling in basal cell carcinoma. J Dermatol Sci. 2015; 78 (2): 95-100.

8. Sobin L.H., Gospodarovich M., Vittekind K. TNM Klassifikaciya zlokachestvennyh opuholej. M: Logosfera, 2011, 288 s. [Собин Л.Х., Господарович М., Виттекинд К. ТNМ Классификация злокачественных опухолей. М: Логосфера, 2011; 288.]

9. Dubenskij V.V., Dubenskij VI.V. Novoobrazovaniya kozhi v praktike dermatovenerologa. Voprosy ehpidemiologii, ehtiopatogeneza i diagnostiki. Vestn dermatol venerol 2008; 6 : 22-40. [Дубенский В.В., Дубенский Вл.В. Новообразования кожи в практике дерматовенеролога. Вопросы эпидемиологии, этиопатогенеза и диагностики. Вестн дерматол венерол 2008; (6): 22-40.]

10. Volgin V.N., Sokolova T.V., Kolbina M.S., Sokolovskaya A.A. Bazal'no-kletochnyj rak kozhi: ehpidemiologiya, patogenez, klinicheskaya kartina (chast' 1). Vestn dermatol venerol 2013; 2: 6-14. [Волгин В.Н., Соколова Т.В., Колбина М.С., Соколовская А.А. Базально-клеточный рак кожи: эпидемиология, патогенез, клиническая картина (часть 1). Вестн дерматол венерол 2013; (2): 6 —14.]

11. Volgin V.N., Sokolova T.V., Kolbina M.S., Sokolovskaya A.A. Bazal'no-kletochnyj rak kozhi: diagnostika, lechenie (chast' 2). Vestn dermatol venerol 2013; 2: 16-23 [Волгин В.Н., Соколова Т.В., Колбина М.С., Соколовская А.А. Базально-клеточный рак кожи: диагностика, лечение (часть 2). Вестн дерматол венерол 2013; (2): 16-23.]

12. Volgin V.N., Sokolova T.V. Osobennosti techeniya bazal'no-kletochnogo raka kozhi $v$ sovremennyh usloviyah. Vrach. 2009; 2: 6—9. [Волгин В.Н., Соколова Т.В. Особенности течения базально-клеточного рака кожи в современных условиях. Врач. 2009; (2): 6—9.]
13. Yantsos V.A., Conrad N., Zabawski E., Cockerell C.J. Incipient intraepidermal cutaneous squamous cell carcinoma: a proposal for reclassifying and grading solar (actinic) keratoses. Semin Cutan Med Surg 1999; 18 (1): 13_-14.

14. Schwartz R.A., Bridges T.M., Butani A.K., Ehrlich A. Actinic keratosis: an occupational and environmental disorder. J Eur Acad Dermatol Venereol 2008; 22 (5): 606_615.

15. Glogau R.G. The risk of progression to invasive disease. J Am Acad Dermatol 2000; 42 (1): 23—24.

16. Ko C.J. Actinic keratosis: facts and controversies. Clin Dermatol 2010; 28 (3): 249—253.

17. Rossi R., Mori M., Lotti T. Actinic keratosis. Int J Dermatol 2007; 46 (9): 895—904.

18. Criscione V.D., Weinstock M.A., Naylor M.F. et al. Actinic keratoses: Natural history and risk of malignant transformation in the Veterans Affairs Topical Tretinoin Chemoprevention Trial Cancer 2009; 115 (11): 2523-2530.

19. Lever L.R., Farr P.M. Skin cancers or premalignant lesions occur in half of high-dose PUVA patients. Br J Dermatol 1994; 131 (2): 215-219.

20. Nindl I., Gottschling M., Krawtchenko N. et al. Low prevalence of p53, p16(INK4a) and Haras tumour-specific mutations in low-graded actinic keratosis. Br J Dermatol 2007; 156, 3: 34-39.

21. Jorizzo J.L., Carney P.S., Ko W.T. et al. Treatment options in the management of actinic keratosis. Cutis 2004; 74 (6): 9-17.

22. Stockfleth E., Ferrandiz C., Grob J.J. et al. Development of a treatment algorithm for actinic keratoses: a European Consensus. Eur J Dermatol 2008; 18 (6): 651—659.

23. Cyb A.F., Kaplan M.A., Romanko Yu.S., Popuchiev V.V. Fotodinamicheskaya terapiya. M: Medicinskoe informacionnoe agentstvo, 2009. [Цыб А.Ф., Каплан М.А., Романко Ю.С., Попучиев В.В. Фотодинамическая терапия. М: Медицинское информационное агентство, 2009.]

24. Stranadko E.F. Istoricheskij ocherk razvitiya fotodinamicheskoj terapii. Lazernaya medicina. 2002; 6 (1): 4-8. [Странадко Е.Ф. Исторический очерк развития фотодинамической терапии. Лазерная медицина. 2002; 6 (1): 4 -8.]
25. Szeimies R.M., Karrer S., Radakovic-Fijan S. et al. Photodynamic therapy using topical methyl 5-aminolevulinate compared with cryotherapy for actinic keratosis: A prospective, randomized study. J Am Acad Dermatol 2002; 47 (2): $258-62$.

26. Morton C., Campbell S., Gupta G. et al. Intraindividual, right-left comparison of topical methyl aminolaevulinate-photodynamic therapy and cryotherapy in subjects with actinic keratoses: a multicentre, randomized controlled study. $\mathrm{Br} \mathrm{J}$ Dermatol 2006; 155 (5): 1029_1036.

27. McIntyre W.J., Downs M.R., Bedwell S.A. Treatment options for actinic keratoses. Am Fam Physician 2007; 76 (5): 667-671.

28. Weinberg J.M. Topical therapy for actinic keratosis: current and evolving therapies. Rev Recent Clin Trials 2006; 1 (1): 53-60.

29. Moan J., Ma L.W., Iani V. On the pharmacokinetics of topically applied 5-aminolevulinic acid and two of its esters. Int J Cancer 2001; 92 (1): 139-143.

30. Casas A., Fukuda H., Di Venosa G., Batlle A. Photosensitization and mechanism of cytotoxicity induced by the use of ALA derivatives in photodynamic therapy. Br J Cancer 2001; 85 (2): $279-284$.

31. Evstifeev S.V., Kulaev M.T., Almyashev A.Z. et al. Fluorescence diagnosis and photodynamic therapy of skin cancer with alasens. Fotodinamicheskaya terapiya I fotodiagnostika. 2014; 4: 13-17. [Евстифеев С.В., Кулаев М.Т., Альмяшев А.З. и соавт. Флюоресцентная диагностика и фотодинамическая терапия рака кожи с препаратом аласенс. Фотодинамическая терапия и фотодиагностика. 2014; (4): 13-17.]

32. Butov Yu.S., Vasenova V.Yu., Ivanova M.S. et al. Actinic keratosis clinical-morphological characteristics and its healing with photodynamic therapy application. Vestn estet med 2012; 1 : 36-42. [Бутов Ю.С., Васенова В.Ю., Иванова М.С. и соавт. Клинико-морфологическая характеристика актинического кератоза и его лечение с применением фотодинамической терапии. Вестн эстет мед 2012; (1): 36-42.]

об авторах:

А.А. Кубанова — д.м.н., профрессор, академик РАН, директор ФГБУ «ГНЦДК» Минздрава России, Москва

А.А. Кубанов - д.м.н., профрессор, зам. директора по научной работе ФГБУ «ГНЦДК» Минздрава России, Москва

И.Н. Кондрахина — К.м.Н., зав. консультативно-диагностическим центром ФГБУ «ГНЦДК» Минздрава России, Москва

Н.В. Грибанов — аспирант ФГБУ «ГНЦДК» Минздрава России, Москва

\section{Конфликт интересов}

Авторы заявляют об отсутствии потенциального конфрликта интересов, требующего раскрытия в данной статье 